\title{
Prevalens dan Faktor Risiko Terjadinya Hipo- zincemia Bayi Berat Lahir Rendah pada Usia Koreksi Mendekati Gukup Bulan atau Gukup Bulan
}

\author{
Risma Kerina Kaban, ${ }^{*}$ Nani Dharmasetiawani, ${ }^{* *}$ Johanes Edy Siswanto ${ }^{* *}$ \\ "Departemen Ilmu Kesehatan Anak, Fakultas Kedokteran Universitas RS Dr. Cipto Mangunkusumo, \\ Jakarta, ${ }^{* *}$ RSIA Budi Kemuliaan, Jakarta, ${ }^{* * *}$ RS Anak Bersalin Harapan Kita, Jakarta
}

\begin{abstract}
Latar belakang. Deposit Seng (Zn) berperan terhadap fungsi metabolik tubuh. Bayi kurang bulan mempunyai cadangan $\mathrm{Zn}$ yang rendah pada masa fetus, kebutuhan $\mathrm{Zn}$ yang tinggi setelah lahir, kapasitas untuk mengabsorbsi dan retensi zat makanan terbatas. Gambaran klinis dari defisiensi Zn yang berat yaitu dermatitis, iritabel, kandidiasis oral, diare, mineralisasi tulang yang buruk, gangguan fungsi motorik dan kognitif, meningkatnya risiko terkena infeksi, dan retardasi pertumbuhan.

Tujuan. Untuk menentukan prevalens dan faktor risiko hipozincemia pada bayi berat lahir rendah.

Metode. Penelitian prospektif, desain penelitian potong lintang. Data dikumpulkan dari 3 rumah sakit di Jakarta. Informasi faktor risiko dicatat dan kadar Zn diperiksa pada bayi dengan berat lahir $\leq 2000 \mathrm{~g}$ dan usia gestasi $\leq 34$ minggu, pada usia koreksi mendekati cukup bulan atau cukup bulan. Hasil dianalisis dengan (T-test, dan Mann-Whitney) (regresi logistik). Defisiensi Zn didiagnosis apabila kadar Zn $<55 \mathrm{mg} /$ dl $(8,4 \mu \mathrm{mol} / \mathrm{L})$.

Hasil. Dari 63 bayi yang diteliti terdapat 18 bayi yang hipozincemia sehingga didapatkan prevalens hipozincemia 28\%. Dari 18 bayi hipozincemia, 67\% disertai dengan gejala yang paling banyak dijumpai adalah gangguan pertumbuhan. Peningkatan usia gestasi, peningkatan kadar kalsium dan pemberian suplemen besi berhubungan dengan penurunan risiko hipozincemia (OR 0,622; 95\% CI: 0,42-0,92), (OR 0,376; 95\% CI: 0,16-0,88) dan (OR 0,062; 95 \% CI: 0,008-0,46). Sedangkan jenis kelamin laki laki berhubungan dengan peningkatan risiko hipozincemia(OR 4,764; 95\% CI: 0,06-21,40).

Kesimpulan. Prevalens hipozincemia pada bayi usia gestasi $\leq 34$ minggu dan berat lahir $\leq 2000$ gram, yang diperiksa pada usia koreksi $\geq 35$ minggu, didapatkan $28 \%$ dengan gejala. Gangguan pertumbuhan merupakan gejala yang paling banyak dijumpai. Faktor risiko hipozincemia ditemukan pada bayi laki-laki, usia gestasi yang lebih rendah, penurunan kadar kalsium dan tanpa pemberian suplementasi besi. Sari Pediatri 2011;13(3):207-14.
\end{abstract}

Kata kunci: bayi berat lahir rendah, faktor risiko, hipozincemia

\footnotetext{
Alamat korespondensi:

Dr. Risma Kerina Kaban, Sp.A. Divisi Perinatologi. Departemen Ilmu

Kesehatan Anak FKUI-RSCM. Jl. Salemba no. 6. Jakarta 10430.

Telepon: 021-3154020
} 
M engingat telah terjadi peningkatan angka kesintasan bayi berat lahir rendah (BBLR), diperlukan untuk mengetahui kebutuhan nutrisinya. Deposit Seng ( $\mathrm{Zn}$ ) pada fetus terjadi pada trimester ketiga, sehingga cadangan $\mathrm{Zn}$ pada bayi kurang bulan sangat rendah. ${ }^{1}$ Deposit $\mathrm{Zn}$ berperan terhadap fungsi metabolik tubuh. ${ }^{1-2}$ Bayi kurang bulan mempunyai cadangan $\mathrm{Zn}$ yang rendah pada masa fetus, kebutuhan Zn yang tinggi setelah lahir, dan kapasitas untuk mengabsorbsi dan retensi zat makanan terbatas. ${ }^{1-4}$ Gambaran klinis dari defisiensi $\mathrm{Zn}$ yang berat adalah dermatitis, irritable, kandidiasis oral, diare, mineralisasi tulang yang buruk, gangguan fungsi motorik, dan kognitif, meningkatnya risiko terkena infeksi dan retardasi pertumbuhan. ${ }^{5-10}$ Dilaporkan defisiensi $Z n$ telah dijumpai pada bayi kurang bulan. ${ }^{1-4}$

Bayi berat lahir rendah, bayi kurang bulan, kenaikan berat badan, jumlah masukan susu, ASI, susu formula, pemberian zat besi, total protein, albumin, calsium, fosfat inorganik, dan alkalin fosfatase merupakan faktor risiko yang diduga mempengaruhi kadar $Z n{ }^{5,11-}$ ${ }^{16}$ Diagnosis defisiensi $\mathrm{Zn}$ yang simtomatik dapat dikerjakan dengan lebih mudah, tetapi menetapkan diagnosis defisiensi $\mathrm{Zn}$ yang asimtomatik masih merupakan suatu masalah. Belum ada data nilai normal kadar Zn serum yang dapat diterima dan masih banyak kesulitan dalam menginterpretasi hasilnya pada bayi kurang bulan. Kadar $\mathrm{Zn}$ telah digunakan secara luas untuk menentukan status nutrisi, tetapi kadar normal Zn belum ditetapkan secara pasti. ${ }^{2}$
Penelitian ditujukan untuk menentukan kadar $\mathrm{Zn}$ plasma, prevalens, faktor risiko, dan gambaran klinis hipozincemia pada BBLR saat usia koreksi mendekati cukup bulan (35-36) minggu atau cukup bulan ( $\geq 37$ minggu).

\section{Metode}

\section{Kelompok penelitian}

Data dikumpulkan dari tiga rumah sakit di Jakarta yang merawat bayi berat lahir rendah pada periode April-Desember 2010. Kriteria inklusi pada penelitian ini adalah pasien yang dirawat di bangsal perinatologi FKUI-RSCM, RSAB Harapan Kita, dan RSIA Budi Kemuliaan, bayi kurang bulan dengan berat lahir $\leq 2000$ gram dan usia gestasi $\leq 34$ minggu, usia koreksi bayi mendekati cukup bulan (35-36) minggu atau cukup bulan ( $\geq 37$ minggu) pada saat dilakukan penelitian. Kriteria eksklusi yaitu bayi yang menderita kelainan kongenital mayor, sepsis, dan menolak ikut serta pada penelitian. Total bayi yang memenuhi kriteria inklusi dan eksklusi adalah 63 bayi dengan usia gestasi (25-34 minggu), berat lahir (600-1850 gram), dan usia koreksi ( $\geq 35$ minggu) masuk ke dalam penelitian (Tabel 1).

Semua informasi mengenai karakteristik bayi, termasuk jenis kelamin, usia gestasi, berat lahir, berat badan saat penelitian, jumlah asupan susu selama satu minggu sebelum penelitian, jenis susu,

Tabel 1. Studi populasi $(\mathrm{n}=63)$

\begin{tabular}{|c|c|}
\hline Karakteristik & Proporsi/Rerata \\
\hline \multicolumn{2}{|l|}{ Jenis kelamin, $\mathrm{n}(\%)$} \\
\hline - Laki-laki & $34(54)$ \\
\hline - Perempuan & $29(46)$ \\
\hline Usia gestasi (minggu, rerata $\pm \mathrm{SB}$ ) & $30,76 \pm 2,33$ \\
\hline Berat lahir (gram, rerata $\pm S B)$ & $1318,29 \pm 301,05$ \\
\hline Usia post-natal saat penelitian (hari, rerata \pm SB) & $40,95 \pm 18,02$ \\
\hline Usia koreksi saat penelitian (minggu, rerata $\pm \mathrm{SB}$ ) & $36,78 \pm 1,04$ \\
\hline Berat badan saat penelitian (gram, rerata $\pm S B)$ & $1875,48 \pm 304,09$ \\
\hline Kenaikan berat badan, $(\mathrm{g} / \mathrm{kg} / \mathrm{hari}$, rerata $\pm \mathrm{SB})$ & $8,48 \pm 3,31$ \\
\hline Asupan susu satu minggu sebelum penelitian $(\mathrm{ml} / \mathrm{kg} /$ hari, rerata $\pm \mathrm{SB})$ & $155,46 \pm 24,27$ \\
\hline \multicolumn{2}{|l|}{ Jenis susu, $\mathrm{n}(\%)$} \\
\hline - ASI & $3(4.8)$ \\
\hline - Susu formula & $46(73)$ \\
\hline - Susu campuran & $14(22,2)$ \\
\hline Pemberian besi & $33(52,4)$ \\
\hline
\end{tabular}

a pemberian susu kombinasi ASI dan susu formula 
data laboratorium seperti kadar Zn, protein total, albumin, kalsium, fosfat inorganik, alkalin fosfatase serum dan adanya gambaran klinis hipozincemia berupa diare, irritable, dermatitis, stomatitis, dan gangguan pertumbuhan (bila kenaikan berat badan tidak mencapai presentil ke 3 kurva pertumbuhan bayi kurang bulan). ${ }^{17}$ Sampel darah untuk menentukan konsentrasi $\mathrm{Zn}$ dan data biokimia lain diambil saat usia koreksi bayi mendekati usia cukup bulan. Protokol yang dilakukan sudah disetujui oleh Komite Etik FKUI-RSCM Jakarta.

Panduan pemberian nutrisi seperti nutrisi parenteral dan minum enteral tergantung masing-masing tempat perawatan. Walaupun tidak didapatkan informasi mengenai formulasi cairan nutrisi parenteral dari setiap tempat perawatan, subyek penelitian dipastikan tidak mendapat suplemen $\mathrm{Zn}$ secara parenteral. Para subyek juga tidak diberikan suplemen Zn secara enteral sebelum dilakukannya penelitian. Bayi yang diberi ASI atau susu formula adalah apabila bayi tersebut mendapatkan asupan susu yang dimaksud sebanyak lebih dari $80 \%$. Jika diluar kriteria tersebut maka kelompok tersebut termasuk subyek dengan pemberian susu campuran. Defisiensi $\mathrm{Zn}$ didiagnosis bila kadar $\mathrm{Zn}<55 \mathrm{mg} / \mathrm{dL}(8,4 \mu \mathrm{mol} / \mathrm{L})^{2}$

Untuk mengukur nilai laboratorium digunakan darah vena. Pengambilan darah yang diperlukan sebanyak $3 \mathrm{cc}$ untuk kemudian dilakukan pengukuran kadar Zn dalam plasma subjek. Plasma dipisahkan dengan menggunakan teknik sentrifugasi lalu ditempatkan dalam wadah yang telah dicuci dengan larutan asam sebelumnya. Kadar Zn plasma diukur menggunakan nat atomic absorbtion spectrophotometer (GBC model 933 AA, Victoria, Australia). ${ }^{18-21}$ Kadar protein, albumin, $\mathrm{Ca}, \mathrm{PO}_{4}$ dan Alkali Phosphatase plasma diperiksa dengan teknik standar dengan autoanalisis menggunakan COBAS 501 [22].

Analisis data hipozincemia dilakukan dengan menilai prevalensi dan analisis faktor risiko. Penilaian prevalensi disajikan secara deskriptif dalam bentuk jumlah dan persentase ( $\mathrm{n} \%)$. Sedangkan analisis faktor risiko bertujuan untuk menentukan hubungan antara berbagai faktor risiko dengan hipozincemia yang terbagi menjadi dua langkah. Pertama, analisis bivariat diuji dengan $\mathrm{X}^{2}$, T-Test dan tes Mann-Whitney $\mathrm{U}$, sekaligus dihitung nilai odds ratio (OR) dan interval kepercayaannya. Langkah kedua adalah analisis multivariat dengan model regresi logistik. Variabel yang masuk analisis multivariat adalah variabel yang pada analisis bivariat mempunyai nilai $\mathrm{p}<0,25$. Hasil dari analisis multivariat dinyatakan dengan odds ratio (OR) dengan interval kepercayaan 95\%. Level yang bermakna untuk semua tes hipotesis adalah $\mathrm{p}<0,05$. SPSS versi 16 digunakan untuk analisis data.

Konsentrasi serum zinc pada 63 subyek BBLR dengan rerata 9,65 $(\mathrm{SB} \pm 2.06) \mu \mathrm{mol} / \mathrm{L}$ dan median 9,49 , konsentrasi minimum $(5,51) \mu \mathrm{mol} / \mathrm{L}$ dan maksimum $(15,61) \mu \mathrm{mol} / \mathrm{L}$ dengan persentil $5(6,18)$, 25 (8,11), 75 (10,71), 95 (13,22). Pada presentase hipozincemia terdapat nilai zinc tidak normal 18 $(28,6 \%)$ dan normal $45(71,4 \%)$ dari jumlah total 63 subyek BBLR.

\section{Hasil}

Konsentrasi $Z n$ dari 63 bayi yang diteliti menunjukkan distribusi normal. Rata-rata kadar $\mathrm{Zn}$ serum adalah 9,65 $\left(\mathrm{SB}_{ \pm} 2,06\right) \mu \mathrm{mol} / \mathrm{L}$. Konsentrasi $\mathrm{Zn}$ serum $<8,4 \mu \mathrm{mol} / \mathrm{L}$ dikelompokkan sebagai hipozincemia. Konsentrasi ini hampir sama dengan kadar $\mathrm{Zn}$ pada persentile ke 25 yaitu $8,11 \mu \mathrm{mol} / \mathrm{L}$. Dari 63 bayi yang diteliti terdapat 18 bayi yang hipozincemia sehingga didapatkan prevalensi hipozincemia $28 \%$. Dari 18 bayi yang hipozincemia, 33\% bayi tanpa gejala dan $67 \%$ bayi disertai gejala. Gambaran klinis yang paling banyak dijumpai adalah gangguan pertumbuhan 66,7\% (Tabel 2). Pada analisis bivariat kita dapatkan bahwa bayi dengan hipozincemia lebih banyak dijumpai pada anak laki-laki $(\mathrm{p}=0,016)$ dan bayi yang mendapat susu campuran dibandingkan dengan susu formula. Sedangkan faktor usia gestasi, berat lahir, usia pasca menstruasi, kenaikkan berat badan, berat badan saat pemeriksaan, pemeriksaan besi, protein total, albumin, kalsium, fosfat organik, dan alkaline fosfatar tidak berbeda bermakna antara kedua kelompok (Tabel 3).

Tabel 2. Deskripsi gambaran klinis pada pasien dengan hypozincemia

\begin{tabular}{lc}
\hline Gambaran Klinis & $\mathrm{n}$ \\
\hline Dermatitis & 1 \\
Irritable & 0 \\
Stomatitis & 1 \\
Diare & 0 \\
Gangguan pertumbuhan & 12 \\
\hline $\mathrm{n}=63$ &
\end{tabular}


Risma Kerina Kaban dkk: Prevalens dan faktor risiko terjadinya hipozincemia

Tabel 3. Analisis bivariat karakteristik bayi menurut ada tidaknya hipozincemia

\begin{tabular}{|c|c|c|c|c|c|}
\hline Karakteristik bayi & $\begin{array}{l}\text { Hipozincemia } \\
\qquad(\mathrm{n}=18)\end{array}$ & $\begin{array}{l}\text { Tidak hipozincemia } \\
\qquad(\mathrm{n}=45)\end{array}$ & $\mathrm{p}$ & OR & IK 95\% \\
\hline \multicolumn{6}{|l|}{ Jenis kelamin (n, \%) } \\
\hline - Laki-laki & $14(41,2)$ & $20(58,8)$ & 0,016 & 4,38 & $1,24-15,38$ \\
\hline - Perempuan & $4(13,8)$ & $25(86,2)$ & & & \\
\hline Usia gestasi (minggu, $\mathrm{n}, \%)$ & $30(25-34)$ & $31(25-34)$ & 0,221 & & \\
\hline Berat lahir $($ gram, rerata $\pm \mathrm{SB}) *$ & $1236.22 \pm 281,02$ & $1351,11 \pm 305,51$ & 0,173 & & \\
\hline Usia pasca natal saat pemeriksaan (hari) & $42,5(20-95)$ & $36(14-80)$ & 0,148 & & \\
\hline $\begin{array}{l}\text { Usia pasca menstruasi saat pemeriksaan } \\
\text { (minggu) }\end{array}$ & $37(36-38)$ & $36(36-41)$ & 0,113 & & \\
\hline Berat badan saat pemeriksaan $(\mathrm{gram}) *$ & $1840,39 \pm 371,56$ & $1889,51 \pm 276,13$ & 0,567 & & \\
\hline Kenaikan berat badan (g/kg/hari) & $8(4-15)$ & $9(2-16)$ & 0,933 & & \\
\hline $\begin{array}{l}\text { Asupan susu selama satu minggu } \\
\text { sebelum pemeriksaan }(\mathrm{ml} / \mathrm{kg} / \mathrm{hari})\end{array}$ & $160(125-200)$ & $150(69-210)$ & 0,339 & & \\
\hline \multicolumn{6}{|l|}{ Jenis susu $(\mathrm{n}, \%)$} \\
\hline - ASI & $1(33,3)$ & $2(66,7)$ & 0,576 & 0,38 & $0,03-5,17$ \\
\hline - Susu formula & $9(19,6)$ & $37(80,4)$ & 0,015 & 0,18 & $0,05-0,66$ \\
\hline - Susu campuran ${ }^{a}$ & $8(57,1)$ & $6(42,9)$ & & & \\
\hline Pemberian besi (\%) & $6(20)$ & $27(80)$ & 0,056 & 0,333 & $0,11-1,05$ \\
\hline \multicolumn{6}{|l|}{ Data laboratorium, rerata $(\mathrm{SB})$} \\
\hline - Protein total $(\mathrm{g} / \mathrm{dl})$ & $4,1(3,5-4,8)$ & $4,2(3,5-5,6)$ & 0,511 & & \\
\hline - Albumin (g/dl) & $3,06 \pm 0,34$ & $3,22 \pm 0,32$ & 0,102 & & \\
\hline - Kalsium (mg/dl) & $8,7(7,1-9,8)$ & $9,1(4,8-11,0)$ & 0,055 & & \\
\hline - Fosfat inorganic (mg/dl) & $6,2(3,2-7,1)$ & $6,3(2,5-8,8)$ & 0,542 & & \\
\hline - Alkalin fosfatase (U/L) & $291,5(161-666)$ & $302(117-964)$ & 0,873 & & \\
\hline
\end{tabular}

${ }^{a}$ pemberian susu kombinasi ASI dan susu formula

* uji t tidak berpasangan, statistik lainnya menggunakan uji Mann-Whitney

Tabel 5. Analisis multivariat untuk memprediksi hipozincemia

\begin{tabular}{lccc}
\hline Faktor risiko & OR & IK 95\% & $\mathrm{p}$ \\
\hline Usia gestasi $(1 \mathrm{minggu})$ & 0,622 & $0,42-0,91$ & 0,015 \\
Kalsium $(1 \mathrm{mg} / \mathrm{dl})$ & 0,376 & $0,16-0,88$ & 0,024 \\
Jenis kelamin (laki-laki) & 4,764 & $1,06-21,40$ & 0,042 \\
Pemberian suplementasi besi & 0,062 & $0,008-0,46$ & 0,007 \\
\hline
\end{tabular}

Faktor risiko yang berhubungan dengan hipozincemia berdasarkan regresi logistik tertera pada Tabel 4. Peningkatan usia gestasi, peningkatan kadar kalsium dan pemberian suplemen besi berhubungan dengan penurunan risiko hipozincemia (OR 0.622; 95\% CI: 0.42-0.92), (OR 0.376; 95\% CI: 0.16 - 0.88) dan (OR 0.062; 95 \% CI: 0.008-0.46). Sedangkan jenis kelamin laki laki berhubungan dengan peningkatan risiko hipozincemia (OR 4.764; 95\% CI: 0.06-21.40) (Tabel 5).

\section{Pembahasan}

Penggunaan konsentrasi $\mathrm{Zn}$ plasma sebagai marker untuk menentukan kadar $\mathrm{Zn}$ cukup sulit, termasuk ketidakpastian tentang variasi nilai normal dan nilai referensi yang berbeda. ${ }^{1-2,23}$ Kadar Zn plasma merupakan presentasi terkecil dari kadar $\mathrm{Zn}$ seluruh tubuh, dan perubahan konsentrasi $\mathrm{Zn}$ plasma pada bayi kurang bulan belum jelas sehingga membuat tatalaksana berdasarkan kadar $\mathrm{Zn}$ plasma saja tanpa 
gejala klinis sangat sulit. ${ }^{2}$ Walaupun perubahan konsentrasi $\mathrm{Zn}$ plasma merupakan indikasi yang tidak sensitif, hipozincemia dapat timbul ketika masukan $\mathrm{Zn}$ sangat rendah sehingga hemostasis tidak bisa dicapai tanpa adanya pergantian $\mathrm{Zn}$ dari tempat penyimpanan. Oleh karena itu $\mathrm{Zn}$ serum merupakan indikator yang berguna dalam menentukan ukuran pergantian Zn dari tempat penyimpanan. ${ }^{24}$ Meta-analisis yang dilakukan oleh Brown dkk ${ }^{25}$ menyatakan bahwa konsentrasi Zn plasma merupakan indikator yang berguna dalam menentukan kadar Zn pada penelitian epidemiologi dalam jumlah besar. Metode yang definitif dalam menentukan defisiensi $\mathrm{Zn}$ adalah respon yang baik terhadap gejala klinis dan laboratorium biokimia bila Zn diberikan. ${ }^{25,26}$ Batasan kadar hipozincemia belum ditentukan pada bayi berat lahir rendah. Diagnosis defisiensi $\mathrm{Zn}$ pada bayi kurang bulan bila kadar Zn serum $<55 \mathrm{mg} / \mathrm{dl}(8.4 \mu \mathrm{mol} / \mathrm{L})$ oleh karena konsentrasi normal $>70 \mathrm{mg} / \mathrm{dl}(10,7 \mu \mathrm{mol} / \mathrm{L})$. Konsentrasi $\mathrm{Zn}$ plasma $>70 \mathrm{mg} / \mathrm{dl}$ cukup untuk seluruh bayi kurang bulan. ${ }^{27}$ Berdasarkan batasan hipozincemia di atas $(<8,4 \mu \mathrm{mol} / \mathrm{L})$, maka presentase defisiensi hipozincemia yang didapat pada penelitian ini sekitar $28 \%$, dan hal ini tidak jauh berbeda dari hasil penelitian Itabashi dkk yaitu $25 \% .{ }^{4}$ Itabashi dkk menggunakan batasan hipozincemia $<7 \mu \mathrm{mol} / \mathrm{L}$.

McMaster $\mathrm{dkk}^{28}$ mengukur kadar $\mathrm{Zn}$ pada bayi dengan usia gestasi 28-36 minggu dan menemukan kadar rata-rata $\mathrm{Zn}$ plasma pada usia 9 minggu $10,9 \pm 1,7 \mu \mathrm{mol} / \mathrm{L}$. Itabashi $\mathrm{dkk}^{4}$ mendapatkan kadar rata-rata $\mathrm{Zn}$ plasma $8,3 \pm 2,2 \mu \mathrm{mol} / \mathrm{L}$ pada bayi berat lahir sangat rendah $1094 \pm 254 \mathrm{~g}$ dengan usia gestasi $29,5 \pm 2,5$ minggu. Pada penelitian kami didapatkan rata-rata $\mathrm{Zn}$ plasma $9,65 \pm 2,06 \mu \mathrm{mol} / \mathrm{L}$ pada bayi usia gestasi $30,7 \pm 2,3$ minggu dan berat lahir $1318 \pm 301 \mathrm{~g}$, hasilnya lebih tinggi dibandingkan dengan rata-rata Zn plasma yang didapatkan oleh Itabashi $\mathrm{dkk} .{ }^{4} \mathrm{Hal}$ ini mungkin disebabkan oleh karena usia gestasi pada penelitian kami, lebih tua. Hasil kami lebih rendah dibandingkan dengan hasil McMaster $\mathrm{dkk}^{28}$ yang mungkin disebabkan oleh karena penelitian oleh McMaster dkk dilakukan pada usia gestasi yang lebih tinggi.

Bayi kurang bulan dengan hipozincemia tidak dapat mencapai keadaan hemostasis oleh karena mempunyai cadangan $\mathrm{Zn}$ rendah sehingga dapat mengalami defisiensi $Z n$ berat. Dari 18 pasien hipozincemia terdapat $12(67 \%)$ pasien yang mempunyai gejala, hal ini bertolak belakang dengan penelitian Itabashi $\mathrm{dkk}^{4}$ yang tidak menemukan gejala pada pasien yang hipozincemia. Gejala yang paling banyak dijumpai pada penelitian kami adalah gangguan pertumbuhan. Hal tersebut dapat dijelaskan karena lebih dari 300 enzim yang tergantung $\mathrm{Zn}$ sudah teridentifikasikan dan sintesis protein juga berhubungan dengan Zn. ${ }^{7,28,29}$ Pemberian Zn mempengaruhi pertumbuhan bayi kurang bulan dan cukup bulan, dengan risiko defisiensi yang lebih tinggi pada bayi kurang bulan sehingga mengakibatkan pertumbuhan yang kurang baik. 25,28,29

Kadar Zn pada ASI menurun dengan bertambahnya waktu. ${ }^{30,31}$ Pada bayi cukup bulan absorbsi $\mathrm{Zn}$ bertambah oleh karena konsentrasi $\mathrm{Zn}$ menurun, sehingga cadangan $\mathrm{Zn}$ di dalam tubuh dimobilisasi untuk mencegah defisiensi $\mathrm{Zn} .{ }^{32}$ Dauncey $\mathrm{dkk}^{33}$ menemukan pemberian ASI tanpa suplementasi $\mathrm{Zn}$ tidak mencukupi kebutuhan $\mathrm{Zn}$ pada bayi kurang bulan. Rata-rata masukan $\mathrm{Zn}$ pada bayi yang diberi ASI bayi kurang bulan lebih rendah dibandingkan bayi kurang bulan dengan susu formula. ${ }^{34}$ Sebaliknya pada penelitian kami didapatkan tidak ada perbedaan yang bermakna terhadap insiden hipozincemia antara pemberian ke 3 jenis susu yang diberi (ASI bayi kurang bulan, susu formula dan ASI+susu formula). $\mathrm{Hal}$ ini mungkin dapat disebabkan absorbsi $\mathrm{Zn}$ dari ASI bayi kurang bulan lebih besar dibandingkan susu formula bayi kurang bulan (kira-kira 65\% dibandingkan dengan $15 \%$ pada susu formula bayi kurang bulan). Oleh karena itu walaupun konsentrasi Zn tinggi pada formula namun absorbsi lebih tinggi pada ASI. Absorbsi Zn dapat diabaikan sehingga tidak terjadi perbedaan yang bermakna terhadap insiden hipozincemia pada bayi yang mendapat ASI atau susu formula.

America Academy of Pediatric Committee of Nutrition merekomendasikan masukan Zn untuk bayi kurang bulan 9,2 $\mu \mathrm{mol} / \mathrm{kg} / \mathrm{hari}^{35}$ sedangkan European Society of Pediatric Gastroenterology and Nutrition ${ }^{36}$ merekomendasikan masukan Zn 10,7 - 13,3 بmol/ $\mathrm{kg} /$ hari. Rekomendasi terbaru untuk masukan $\mathrm{Zn}$ enteral untuk bayi kurang bulan selama periode yang stabil berdasarkan kalkulasi terbaru fetal accretion and absorption rates adalah $15,3 \mu \mathrm{mol} / \mathrm{kg} / \mathrm{hari} .{ }^{37}$

Penyebab hipozincemia pada bayi kurang bulan yang diberi susu formula masih membutuhkan penelitian lanjutan oleh karena pada penelitian kami kadar $\mathrm{Zn}$ dalam susu formula yang diberikan sudah mencukupi rekomendasi kebutuhan $\mathrm{Zn}$ untuk bayi 
kurang bulan $(16,2 \mu \mathrm{mol} / \mathrm{Kg} / \mathrm{hr})$. Pada analisis statistik multivariat didapatkan bahwa hipozincemia berhubungan dengan beberapa faktor risiko yaitu usia gestasi, kadar kalsium, jenis kelamin, dan pemberian zat besi. Semakin tinggi usia gestasi semakin berkurang risiko terjadi hipozincemia. Penimbunan $\mathrm{Zn}$ terjadi pada trimester ketiga kira-kira 60\% yaitu $249 \mu \mathrm{g} / \mathrm{kg} /$ hari. ${ }^{31,38}$ Penelitian terakhir mendapatkan penimbunan Zn semakin meningkat menjadi $1420 \mu \mathrm{g} / \mathrm{kg} / \mathrm{hari}$ pada usia gestasi $24 \mathrm{minggu},>850 \mu \mathrm{g} / \mathrm{kg} / \mathrm{hr}$ pada usia gestasi 28 minggu, dan $472 \mu \mathrm{g} / \mathrm{kg} /$ hari pada usia gestasi 32 minggu.$^{39}$ Akumulasi Zn terjadi di hati, dari penyimpanan di dalam hati akan dikeluarkan untuk mengatasi defisiensi $\mathrm{Zn}$. Hal tersebut akan menjadi masalah pada bayi kurang bulan karena penyimpanan $\mathrm{Zn}$ pada hati belum cukup. ${ }^{40}$ Sehingga sangat beralasan apabila semakin meningkat usia gestasi maka risiko hipozincemia semakin berkurang, oleh karena cadangan $\mathrm{Zn}$ di dalam hati semakin meningkat.

Kadar Zn di absorbsi di usus halus dan besar. ${ }^{31}$ Absorbsi ditingkatkan oleh protein, asam amino dan laktosa dan berkurang oleh phytate (pada susu soya), kalsium, besi, dan magnesium..$^{41}$ Pada penelitian kami dapatkan peningkatan kadar kalsium akan mengurangi risiko hipozincemia. Mengapa hal ini terjadi sulit dijelaskan dan mungkin memerlukan penelitian lebih lanjut. Jenis kelamin laki-laki berhubungan dengan peningkatan risiko hipozincemia, oleh karena median konsentrasi $\mathrm{Zn}$ pada bayi laki-laki secara bermakna lebih rendah bila dibandingkan dengan bayi perempuan. ${ }^{41}$

Masukan satu trace element akan mempengaruhi absorbsi dari trace element yang lain. Besi dan $\mathrm{Zn}$ menggunakan jalur yang sama untuk absorpsi dan berkompetensi untuk masuk ke mukosa sel. ${ }^{4}$ Friel $\mathrm{dkk}^{14}$ melaporkan bahwa peningkatan masukan $\mathrm{Zn}$ pada susu formula tidak mempengaruhi absorpsi besi pada bayi kurang bulan. Beberapa penelitian sebelumnya menyatakan bahwa pemberian zat besi yang sesuai tidak mempengaruhi kadar $\mathrm{Zn}$ plasma. ${ }^{4,5,42}$ Sedangkan Solomon dkk $^{13}$ mendapatkan bahwa pemberian zat besi yang berlebihan dapat mengurangi absorbsi Zn. Namun kami mendapatkan pemberian zat besi mengakibatkan berkurangnya hipozincemia. Mengapa hal ini terjadi sulit dijelaskan dan mungkin memerlukan penelitian lebih lanjut tentang kadar zat besi yang diberikan. Berapa kadar zat besi yang diberikan tidak ditanyakan, hanya keterangan bahwa subjek mendapat zat besi atau tidak. Penelitian kami masih berlanjut untuk mendapatkan jumlah subjek yang lebih banyak.

Dari penelitian kami menyimpulkan bahwa prevalens hipozincemia pada bayi usia gestasi $\leq 34$ minggu dan berat lahir $\leq 2000$ gram, 28\% dengan gejala dan tanpa gejala. Gangguan pertumbuhan merupakan gejala yang paling banyak dijumpai. Faktor risiko hipozincemia ditemukan pada bayi laki-laki, usia gestasi yang lebih rendah, penurunan kadar kalsium dan tanpa pemberian suplementasi besi.

\section{Ucapan terimakasih}

Terima kasih kepada DR.Dr. Ina S. Timan, SpPK(K), Ketua Departemen Patologi Klinik RSCM, Dr. Drupadi.H.S. Dillon, Deputi program SEAMEO RECFON dan PT COMBIPAR untuk dukungan selama menyelesaikan penelitian.

\section{Daftar pustaka}

1. Anonymous. Nutritional needs of low-birth-weight infants. Committee of Nutrition 1985; 976-86.

2. Giles E, Doyle LW. Zinc in Extremely Low-birthweight or Very Preterm Infants. NeoReviews 2007; 8: e165-72.

3. Tyrala EE. Zinc and copper balances in preterm infants. Pediatrics 1986; 77: 513-7.

4. Itabashi K, Saito T, Ogawa Y, Uetani Y. Incidence and predicting factors of hypozincemia in very-low-birthweight infants at near-term postmenstrual age. Biol Neonate 2003; 83: 235-40.

5. Obladen M, Loui A, Kampmann W. Zinc deficiency in rapidly growing preterm infants. Acta Paediatric 1998; 87: 685-91.

6. Aggett PJ, Atherton DJ, More J, Davey J, Delved HT, Harries JT. Symptomatic zinc deficiency in a breast-fed preterm infant. Arch Dis Child 1980; 55: 547-50.

7. Salgueiro MJ, Zubillaga MB, Lysionek AE, Caro EA, Weill R, Boccio JR. The role of zinc in the growth and development of children. Nutrition:2002; 18: 510-18.

8. Black MM, The evidence linking zinc deficiency with children's cognitive and motor functioning. J Nutr 2003; 133(5): 1473S-6S.

9. Hambidge M. Human zinc deficiency. J Nutr 2000; 130: 1344S-9S. 
10. Sazawal S, Black RE, Menon VP, Dinghra P, Caulfield LE, Dinghra E. Zinc supplementation in infants born small for gestational age reduces mortality: a prospective, randomized, controlled trial. Pediatrics 2001; 108: 1280-6.

11. Walravens PA. Nutritional importance of copper and zinc in neonates and infants. Clin Chem 1980; 26: 185-9.

12. Jalla S, Krebs N, Rodden D, Hamrbidge M. Zinc homeostasis in premature infants does not differ between those fed preterm formula or fortified human milk. Pediatr res 2004; 56: 615-20.

13. Solomons NW. Competitive interaction of iron and zinc in the diet: consequences for human nutrition. J Nutr 1986; 116: 927-35.

14. Friel JK, Serfass RE, Fennessey PV, Miller L, Andrews WL, Simmons BS, Downton GF, Kwa PG. Elevated intakes of zinc in infant formulas do not interfere with iron absorption in premature infants. J Pediatr Gastroenterol Nutr 1998; 27: 312-6.

15. Kumar SP, Anday EK. Edema, hypoproteinemia, and zinc deficiency in low-birth-weight infants. Pediatrics 1984; 73: 327-9.

16. Zhou JR, Canar MM, Erdman JW Jr. Bone zinc is poorly released in young, growing rats fed marginally zinc-restricted diet. J Nutr 1993; 123: 1383-8.

17. WHO. Fetal-infant growth chart for preterm infants, Fetal Growth chart 2003. WHO, Geneva 2003.

18. Kelson JR, Shamberger RJ. Methods compared for determining zinc in serum by flame atomic absorption spectroscopy. Clin Chem 1978; 24: 240-4.

19. Saleh A, Udall JN, Solomons NW. Minimizing contamination of specimens for zinc determination. Clin Chem 1981; 27: 338-9.

20. Smith Jr JC, Butrimovitz GP, Purdy WC. Direct measurement of zinc in plasma by atomic absorption spectroscopy. Clin Chem 1979; 25: 1487-1.

21. Taylor A, Bryant TN. Comparison of procedures for determination of copper and zinc in serum by atomic absorption spectroscopy. Clinica chimica acta 1981; 110: 83-90.

22. ROCHE, C 501 Chemical analyzer kit. America: 2010.

23. Klein CJ. Nutrient requirements for preterm infant formulas. J Nutr 2002; 132: 1395S-7S.

24. King JC. Assessment of zinc status. Journal of Nutrition 1990; 120(11 Suppl): 1474-9.

25. Brown KH, Peerson JM, Rivera J, Allen LH. Effect of supplemental zinc on the growth and serum zinc concentrations of prepubertal children: a meta-analysis of randomized controlled trials. Am J Clin Nutr 2002; 75: 1062-71.
26. Wood RJ. Assessment of marginal zinc status in humans. J Nutr 2000; 130: 1350S-4S.

27. Hambridge K, Thureen P, Hay W Jr. Neonatal nutrition and metabolism. Edisi ke-dua. 2006, Cambridge, United Kingdom: Cambridge University Press.

28. McMaster D, Lappin TRJ, Halliday HL, Paterson CC. Serum copper and zinc levels in the preterm infant. A Longitudinal Study of the First Year of Life. Biol Neonate 1983; 44: 108-13.

29. Koo WWK, Succop P, Hambridge KM. Serum alkaline phosphatase and serum zinc concentrations in preterm infants with rickets and fractures. Am J Dis Child 1989; 143: 1342-5.

30. Hemalatha P, Bhaskaram P, Kumar PA, Khan MM, Islam MA. Zinc status of breastfed and formula-fed infants of different gestational ages. J Trop Pediatr 1997; 43: 52-4.

31. Aggett P, Cowet R. Neonatal trace element metabolism. Principle of Perinatal-neonatal Metabolism. Edisi ke-dua. New York: Springer Verlag, 1998. h. 909-42.

32. Krebs, NF, Hambridge KM. Zinc requirements and zinc intakes of breast-fed infants. Am J Clin Nutr 1986; 43: 288-92.

33. Dauncey MJ, Shaw JCL, Urman J. The absorption and retention of magnesium, zinc, and copper by low birth weight infants fed pasteurized human breast milk. Pediatr Res 1977; 11: 1033-9.

34. Itabashi K, Miura A, Okuyama K, Takeuchi T, Kitazawa S. Estimated nutritional intake based on the reference growth curves for extremely low birthweight infants. Pediatr Intern 1999; 41: 70-7.

35. American Academy of Pediatrics Committee on Nutrition: Nutritional need for low birth weight infants, Pediatrics 1985; 75: 976-86.

36. ESPHAGAN Committee on Nutrition of the Preterm infant: Nutrition and Feeding of preterm infants. Acta Paediatr Scand 1987; 78 (suppl 336): 2-14.

37. Reifen R, Zlotkin S. Microminerals ; in Tsang RC, Lucas A, Uauy R, Zlotkin Sm Ha WW Jr, penyunting. Nutritional needs of the preterm infants. Baltimore: Williams \& Wilkins; 1993. h. 119-33.

38. Wastney ME, Angelus P, Barnes RM, Subramanian KM. Zinc kinetics in preterm infants: a compartmental model based on stable isotope data. Am J Physiol 1996; 271: R1452-9.

39. Aggett PJ, Trace elements of the micropremie. Clin Perinatol 2000; 27: 119-29.

40. Klein CJ. Nutrient requirements for preterm infant formulas. J Nutr 2002; 132: 1395S-549S. 
41. Zlotkin SH, Atkinson S, Lockith G. Trace elements in nutrition for premature infants. Clin Perinatol 1995; 22: $223-40$.
42. Salvioli GP, Faldella G, Alessandroni R, Lanari M, Benfenati L. Plasma zinc concentrations in iron supplemented low birthweight infants. Arch Dis Child 1986; 61: 346-8. 